\begin{tabular}{|c|} 
Jurnal Keolahragaan \\
Volume 4 - Nomor 2, September 2016, (186-195) \\
Tersedia online: http://journal.uny.ac.id/index.php/jolahraga
\end{tabular}

\title{
PENGEMBANGAN MODEL PEMBELAJARAN MOTORIK KASAR SISWA TAMAN KANAK-KANAK KELOMPOK A
}

\author{
Nuridin Widya Pranoto \\ Universitas Lampung. Jalan Sumantri Brojonegoro No. 01, Lampung 35141, Indonesia \\ Korespondensi Penulis. Email: tone_to@yahoo.co.id
}

Received: 16 September 2016; Revised: 3 October 2016; Accepted: 3 October 2016

\begin{abstract}
Abstrak
Penelitian ini bertujuan menghasilkan model pembelajaran motorik kasar siswa TK kelompok A. Penelitian ini menggunakan desain penelitian pengembangan. langkah-langkahnya terdiri atas (1) potensi dan masalah, (2) pengumpulan data, (3) desain produk, (4) validasi desain, (5) revisi desain, (6) uji coba produk, (7) revisi produk, (8) uji coba pemakaian, dan (9) revisi produk. Penilaian kualitas produk melibatkan 3 orang ahli. Instrumen yang digunakan untuk mengumpulkan data adalah petunjuk umum wawancara, catatan lapangan, lembar evaluasi, angket skala nilai validasi, rubrik penilaian siswa, pedoman observasi permainan, dan pedoman observasi keefektifan permainan. Hasil penelitian berupa model pembelajaran motorik kasar siswa TK kelompok A yang terdiri atas 10 permainan, yaitu: (1) permainan tebak hewan, (2) permainan ular mencari makan, (3) permainan lari citah, (4) permainan mencari hewan, (5) permainan mengambil hewan, (6) permainan loncat kangguru, (7) permainan lompat bangau, (8) permainan lubang tikus, (9) permainan ikan sapu-sapu, dan (10) permainan undur-undur yang telah di validasi oleh ahli dan guru.
\end{abstract}

Kata Kunci: model, pembelajaran, motorik kasar, TK kelompok A

\section{ROUGH LEARNING MOTOR MODEL DEVELOPMENT KINDERGARTEN STUDENT GROUP A}

\begin{abstract}
This research aims to produce a gross motor teaching model for group A kindergarten students. The study used research and development design. consisting the steps of (1) the potential and problems, (2) data collection, (3) product design, (4) validation of the design, (5) revision of the design, (6) product trials, (7) product revision, (8) utility testing, and (9) product revision. 3 Product quality assessment involving experts. The instruments used to collect the data were a general interview guide, field notes, evaluation sheets, questionnaire of validation of the value scale, student assessment rubric, game observation guide, and game effectiveness observation guide. The result of the research is a model of gross motor teaching of group A kindergarten students consisting of 10 games, namely: (1) animal guessing game, (2) foraging snake game, (3) run cheetah game, (4) seeking animal game, (5) taking animal game, (6) jumping kangaroo game, (7) jumping stork game, (8) rat hole game, (9) fish broom game, and (10) undur-undur game that have been validated by experts and teachers.
\end{abstract}

Keywords: models, learning, gross motor skills, kindergarten group A

How to Cite: Pranoto, N. (2016). Pengembangan model pembelajaran motorik kasar siswa taman kanak-kanak kelompok A. Jurnal Keolahragaan, 4(2), 186 - 195. doi:http://dx.doi.org/10.21831/jk.v4i2.10900

Permalink/DOI: http://dx.doi.org/10.21831/jk.v4i2.10900 


\section{PENDAHULUAN}

Anak usia dini merupakan aset bangsa yang sangat berharga sebab anak-anak merupakan generasi yang akan memimpin bangsa di masa depan. Baik buruknya nasib bangsa di masa depan bergantung dari kualitas anak-anak bangsa saat ini. Semakin baik kualitas anak maka semakin baik kualitas bangsa dan semakin buruk kualitas anak maka akan menyebabkan menurunnya kualitas bangsa di masa mendatang.

Menyadari pentingnya kualitas anak pemerintah melalui Kementerian Pendidikan membuat program pendidikan anak usia dini (PAUD). Salah satu pendidikan untuk anak usia dini adalah Taman kanak-kanak. Taman kanakkanak (TK) merupakan salah satu jenjang pendidikan formal yang ditujukan untuk anak usia 4-6 tahun. Pada jenjang pendidikan TK tahapan pembelajaran dibagi menjadi dua kelompok. Tahap pertama merupakan kelompok A ditujukan untuk anak yang usianya 4-5 tahun dan tahap kedua merupakan kelompok B ditujukan untuk anak usia 5-6 tahun. Pembagian kelompok belajar pada jenjang pendidikan TK ditujukan agar pembelajaran yang dilakukan disesuaikan dengan perkembangan fisik dan psikis anak.

Fokus pembelajaran yang diterapkan pada lembaga pendidikan TK tidak boleh sembarang dilakukan. Pada jenjang pendidikan TK kelompok A terdapat beberapa aspek yang diajarkan yaitu: aspek agama dan moral, fisik, kognitif, bahasa, dan sosial emosional. Aspek fisik motorik merupakan standar patokan untuk merangsang perkembangan motorik siswa TK. Pembelajaran fisik motorik dibagi menjadi dua yaitu motorik halus dan motorik kasar. Motorik kasar adalah pembelajaran melalui aktifitas jasmani yang melibatkan otot-otot besar. Pembelajaran motorik kasar bertujuan untuk meningkatkan potensi fisik anak sehingga dapat berguna bagi kegiatan anak sehari-hari. Pembelajaran motorik kasar tidak begitu saja berjalan dengan mulus, terkadang terdapat kendala-kendala yang dialami guru maupun siswa seperti minimnya model pembelajaran yang diketahui guru, kurang bervariasinya pola permainan motorik kasar, kurang mengertinya guru akan tahapan pembelajaran motorik kasar, dan kurangnya antusias siswa mengikuti kegiatan motorik kasar yang dilakukan. Berdasarkan permasalahan tersebut maka penelitian yang akan dilakukan adalah mengembangkan model permainan motorik kasar siswa TK kelompok A.

Asumsi dari pengembangan model pembelajaran motorik kasar untuk siswa TK kelompok A yaitu dihasilkannya sebuah produk berupa buku dan CD yang berisi tutorial dalam mengajarkan permainan motorik kasar bertemakan hewan. Diharapkan dengan adanya pengembangan model permainan motorik kasar bertemakan gerak hewan siswa akan terangsang untuk melakukan gerakan-gerakan yang secara tidak langsung memelajarkan keterampilan motorik kasar.

Pengembangan model pembelajaran merupakan suatu terobosan yang dilakukan dengan cara menciptakan model baru pada proses pembelajaran. Pengembangan model pembelajaran bertujuan untuk mengefektifkan dan mengefisiensikan pencapaian tujuan pembelajaran. Menurut (Isjoni, p.8) model pembelajaran merupakan strategi yang digunakan oleh guru untuk meningkatkan motivasi belajar, sikap belajar, pola berpikir kritis, keterampilan sosial, dan pencapaian hasil pembelajaran. Untuk mengembangkan suatu model pembelajaran terdapat beberapa faktor yang harus diperhatikan di antaranya: harus melihat kesesuaian sifat dan syarat model pembelajaran yang akan diterapkan, harus memperhatikan alat atau media yang dibutuhkan oleh model tersebut dan perhatikan alat atau media yang dapat kita sediakan, sesuaikan materi pelajaran, tujuan, alokasi waktu, waktu yang dibutuhkan dalam persiapan pelaksanaan kegiatan dengan model yang dipilih, perhatikan karakteristik umum anak didik agar penggunaan model tidak membingungkan atau kontraproduktif pada anak didik, ukur kemampuan calon pengguna dalam pembutan model pembelajaran.

Menurut Rusman (2010, p.136) untuk menyusun model pembelajaran terdapat beberapa ciri yang harus diupayakan diantaranya memiliki bagian-bagian model yang dinamakan: (1) Langkah-langkah pembelajaran (syntax). Syntax menjelaskan langkah pelaksanaan suatu model, bentuk kegiatan, bagaimana memulainya, dan apa tindakan selanjutnya. Syntax pada model pembelajaran motorik kasar disusun dengan menjelaskan pelaksanaan kegiatan pembelajaran, menjelaskan aktivitas kegiatan. (2) Prinsip-prinsip reaksi menggambarkan bagaimana seharusnya guru memandang, memperlakukan dan merespon siswa. Pada model pembelajaran motorik kasar prinsip reaksi terlihat dari respon siswa terhadap model 


\section{Jurnal Keolahragaan 4 (2), September 2016 - 188}

Nuridin Widya Pranoto

yang dibuat. (3) Sistem sosial adalah suasana atau norma yang berlaku dalam pembelajaran. Pada model pembelajaran motorik kasar sistem sosial tercermin dari kerjasama siswa saat melakukan permainan.

Menurut Sugiyanto (2008, p.56) terdapat beberapa model yang dapat dipergunakan untuk mengoptimalkan kondisi belajar. Model pembelajaran tersebut terdiri atas model pembelajaran kontekstual, model pembelajaran kooperatif, model pembelajaran kuantum, model pembelajaran terpadu dan model pembelajaran berbasis masal. Model pembelajaran motorik kasar yang dikembangkan berjenis model pembelajaran kontekstual dan berpusat pada anak. Model pembelajaran konseptual tercermin dari sistem pembelajaran yang menghubungkan materi pelajaran dengan situasi dunia nyata. Model pembelajaran berpusat pada anak tercermin dari kerja sama kelompok yang dilakukan pada permainan. Penghubungan kegiatan belajar dengan situasi dunia nyata dan berkelompok dapat mendorong siswa untuk membuat hubungan antara pengetahuan yang dimilikinya dengan penerapan pada kehidupan sehari-hari dan memiliki rasa toleransi dalam bekarjasama. Pemanfaatan pendekatan model kontekstual dan kelompok dalam pembelajaran motorik kasar akan merangsang siswa TK kelompok A melakukan gerakan motorik kasar secara sukarela dan gembira.

Pembelajaran motorik kasar yng dilakukan dari usia dini dapat membentuk gerakan yang baik, efektif, dan memberikan efek senang. Pembelajaran motorik kasar tidak boleh sembarangan dilakukan, terdapat urutan pembelajaran yang disesuaikan dengan kemampuan anak. Berikut tahapan pembelajaran motorik anak usia 4 tahun atau siswa kelompok A: (1) berdiri di atas satu kaki selama 10 detik, (2) berjalan maju dalam satu garis lurus dengan tumit dan ibu jari sejauh 6 kaki, (3) berjalan mundur dengan ibu jari ke tumit, (4) lomba lari, (5) melompat ke depan 10 kali, (6) melompat ke belakang sekali, (7) berguling ke depan, (8) menendang secara terkoordinasi ke belakang dan ke depan dengan kaki terayun dan tangan mengayun ke arah berlawanan secara bersamaan, (9) dengan dua tangan menangkap bola yang dilemparkan dari jarak $3 \mathrm{kaki}$, (10) melempar bola kecil dengan kedua tangan ke pada seseorang yang berjarak 4-6 kaki darinya, (11) membangun menara setinggi 11 kotak, (12) menggambar sesuatu yang berarti bagi anak tersebut dan dapat dikenali orang lain, (13) mempergunakan gerakan-gerakan jemari selama permainan jari, (14) menjiplak gambar kotak, (15) menulis beberapa huruf.

Berdasarkan tahap perkembangan motorik, maka model pembelajaran motorik kasar yang dibuat berpatokan pada tahapan perkembangan motorik anak usia 4-5 tahun. Pengadopsian ini bertujuan agar pengembangan model pembelajaran motorik kasar yang dilakukan sesuai dengan proses tahapan perkembangan anak sehingga dalam proses pelaksanaan kegiatan pembelajaran sesuai dengan kebutuhan perkembangan anak.

Pembelajaran motorik kasar dapat dilakukan dengan berbagai cara, salah satu cara yang efektif adalah melalui bermain. Dharmamulya, dkk (2008, p.21) menjelaskan bahwa bermain merupakan aktivitas yang berfungsi menanamkan nilai-nilai masyarakat dan sosialisasi anakanak. Menurut Partini (2010, p.50) bermain bermanfaat bagi semua bidang perkembangan baik motorik, bahasa, intelektual, moral, sosial, maupun emosional. Berdasarkan penjelasan para ahli dapat disimpulkan bahwa aktifitas bermain memiliki banyak manfaat untuk perkembangan fisik dan psikis anak.

Permainan menirukan gerak hewan merupakan permainan yang didesain untuk pembelajaran motorik kasar siswa TK kelompok A. Konsep permainan motorik kasar menirukan gerak hewan adalah membelajarkan siswa gerak berlari, melompat, meloncat, melampar, menangkap, menendang, mendorong, dan mengangkat beban tubuh sendiri. Permainan gerak hewan dirasa baik dilakukan pada siswa TK kelompok A karena pada usia 4-5 tahun anak memiliki karakteristik suka mencontoh gerakan yang sering dilihat, suka berimajenasi dan mengeluarkan ide-ide pada dirinya.

Menurut (Hughes, 2010, p.113) ketika anak menirukan suatu peran, secara tidak langsung anak telah belajar suatu keterampilan dan menyerap nilai moral yang terkandung di dalam peran tersebut. Berikut keuntungan yang diperoleh dari aktivitas bermain menirukan gerak hewan: (1) membuang ekstra energi, (2) mengoptimalkan pertumbuhan seluruh bagian tubuh, (3) mengetahui berbagai jenis hewan dan gerakannya, (4) dapat meningkatkan nafsu makan, (5) anak belajar mengontrol diri, (6) berkembangnya berbagai keterampilan yang akan berguna sepanjang hidupnya, (7) meningkatkan daya kreatifitas, (8) dapat mengembangkan kemampuan intelektual, (9) belajar mengikuti aturan-aturan. (10) belajar bersosialisasi. 
Berasumsi dari manfaat yang diperoleh dalam permainan gerak hewan maka model pembelajaran motorik kasar yang didisain berkonsepkan menirukan gerak hewan. Permainan menirukan gerak hewan yang dibuat terdiri atas peniruan gerak ular, gerak cheetah, gerak kangguru, gerak bangau, gerak ikan sapu-sapu, dan gerak undur-undur.

\section{METODE}

Metode penelitian yang digunakan dalam penelitian ini adalah penelitian dan pengembangan (research and development). Menurut Sugiyono (2011, p.297) penelitian pengembangan merupakan penelitian yang digunakan untuk menghasilkan produk tertentu, dan menguji keefektifan produk tersebut. Gall \& Borg (2003, p.569) menyatakan bahwa penelitian dan pengembangan menggunakan temuan penelitian untuk merancang prosedur dan produk baru, kemudian secara sistematis diuji di lapangan, dievaluasi, dan disempurnakan sampai memenuhi kriteria tertentu dari unsur efektivitas, kualitas, atau standar yang sama.

Pelaksanaan penelitian ini pendekatan mengadopsi dari Sugiyono. Penggunaan metode Sugiyono diadopsi karena langkah-langkah pengembangan lebih mudah dipahami. Terdapat sepuluh langkah pada penelitian pengembangan menurut Sugiyono (2011, p.297) yaitu: (1) menggali potensi dan masalah, (2) pengumpulan data, (3) Desain produk, (4) validasi desain, (5) revisi desain, (6) uji coba produk, (7) revisi produk, (8) uji coba pemakaian, (9) revisi produk, (10) produksi masal.

Pada penelitian ini diadopsi sembilan langkah prosedur penelitian. Sembilan langkah tersebut yaitu (1) menggali potensi dan masalah, (2) pengumpulan data, (3) Desain produk, (4) validasi Desain, (5) revisi Desain, (6) uji coba produk, (7) revisi produk, (8) uji coba pemakaian, (9) revisi produk. Berikut dijelaskan sembilan langkah yang akan dilakukan.

\section{Potensi dan Masalah}

Masalah yang ada dalam penelitian ini adalah terkendalanya guru TK kelompok A untuk mencari model pembelajaran motorik kasar. Kendala yang dihadapi para guru karena minimnya sarana prasarana dan model pembelajaran motorik kasar siswa TK kelompok A. Berangkat dari permasalahan yang ada maka muncullah gagasan untuk membuat model pembelajaran motorik kasar bagi siswa TK kelompok A dengan bertemakan hewan dan berkon- sepkan menggunakan peralatan yang ekonomis dan memanfaatkan lingkungan sekitar.

Pada penelitian ini pengumpulan data dilakukan dengan cara observasi lapangan, dan meminta penilaian oleh para ahli pada angket observasi model dan keefektifan model.

Pada penelitian ini produk yang dihasilkan berupa buku dan CD yang di dalamnya memuat panduan dan pelaksanaan pembelajaran motorik kasar yang berkonsepkan permainan bertemakan hewan. Desain yang dibuat mengarah pada panduan kurikulum 2013 dan tingkat pencapaian perkembangan siswa TK kelompok A.

Validasi dilakukan oleh ahli yang berkompeten bertujuan untuk mengetahui kelemahan dan kelebihan produk. Pada penelitian ini peneliti meminta validasi dari tiga pakar, yaitu (1) pakar pendidikan jasmani anak usia dini, (2) pakar permainan anak usia dini, (3) pakar pendidik anak usia dini.

Langkah selanjutnya setelah model divalidasi adalah uji coba produk. Pada pelaksanaan uji coba para pakar menilai kelemahan dan kelebihan dari produk yang dibuat. Kelemahan yang telah diketahui diperbaiki agar produk yang dihasilkan menjadi lebih baik.

Uji coba skala kecil merupakan uji coba lapangan dengan jumlah subjek lebih sedikit. Uji coba skala kecil berguna untuk mengetahui kekurangan-kekurangan yang ada pada produk. Uji coba skala kecil pada penelitian ini dilakukan pada TK Happy Holy Kids dengan jumlah siswa sebanyak 20 anak.

Langkah selanjutnya setelah dilakukan uji coba skala kecil adalah melakukan revisi ulang pada produk yang dibuat. Revisi didasari dari pendapat dan masukan para ahli yang bertujuan memperbaiki produk sehingga layak dilakukan uji cobakan pada skala yang lebih besar.

Uji coba pemakaian atau uji coba skala besar merupakan uji lapangan yang dilakukan dengan jumlah subjek yang lebih besar dari uji skala kecil. Uji coba skala besar dilakukan untuk mengetahui apakah produk yang dihasilkan dapat dipergunakan kepada subjek yang lebih besar. Pada penelitian ini uji coba skala besar dilaksanakan pada TK Harapan dan TK Sari Asih 1 Sleman Yogyakarta dengan jumlah keseluruhan siswa sebanyak 38 orang. Setelah uji coba dilaksanakan kemudian dilihat efektifitas produk yang dikembangkan, sehingga diketahui tingkat efektifitas produk. 
Langkah selanjutnya setelah dilakukan uji coba skala besar adalah memperbaiki beberapa hal yang masih dianggap kurang oleh ahli. Perbaikan dilakukan agar produk yang dihasilkan benar-benar layak dipergunakan oleh masyarakat luas.

\section{Desain Uji Coba}

Uji coba dilakukan untuk mendapatkan informasi tentang pelaksanaan model dan keefektifan model yang dikembangkan. Ada tiga bentuk Desain uji lapangan yaitu, uji lapangan awal, uji lapangan utama, uji lapangan operasional.Uji coba awal dilakukan bertujuan untuk menguji produk pada subjek terbatas yang bermanfaat memberikan gambaran terhadap produk yang akan dibuat. Uji lapangan utama bertujuan untuk mengetahui tingkat kelayakan akan model yang dibuat. Uji lapangan operasional dilakukan untuk mengetahui tingkat keefektifan model yang dibuat. Hasil uji lapangan diperoleh dengan cara meminta penilaian para para ahli yang terdiri atas ahli olahraga, ahli usia dini, dan ahli pendidikan usia dini terhadap pelaksanaan model yang dilakukan.

\section{Subjek Coba}

Subjek coba merupakan orang atau subjek yang dituju untuk memperaktekkan pengembangan yang dilakukan. Subjek pada penelitian ini ditentukan menggunakan teknik purposive sample dimana cara pengambilan sampel berdasarkan pertimbangan dari peneliti. Subjek coba pada penelitian ini terbagi menjadi dua yaitu pada uji coba skala kecil peneliti di TK Happy Holy Kids melibatkan 20 orang siswa dan pada tahap uji coba skala besar di dua TK yaitu TK Harapan dengan jumlah siswa sebanyak 15 dan TK Sari Asih 1 dengan jumlah siswa sebanyak 20.

\section{Jenis Data}

Data yang dikumpulan dari penelitian ini berupa data kualitatif dan kuantitatif. Data kualitatif diperoleh dari hasil wawancara dengan guru TK. Data kekurangan model permainan dari ahli materi dan guru pelaku uji coba. Data masukan ahli materi dan guru pelaku uji coba. Data kuantitatif diperoleh dari penilaian ahli materi terhadap permainan. Penilaian ahli materi terhadap keefektifan permainan. Penilaian ahli materi terhadap guru pelaku uji coba.

\section{Teknik dan Instrumen Pengumpulan Data}

Teknik pengumpulan data adalah cara yang dilakukan untuk memperoleh data. Teknik yang dipergunakan pada penelitian ini adalah observasi, wawancara, dan angket. Instrumen pengumpulan data merupakan alat yang dipergunakan untuk mengukur hasil penelitian. Pemilihan jenis instrumen tidak boleh sembarang dilakukan, sebab instrumen menentukan hasil dari penelitian yang dilaksanakan. Instrumen yang dipergunakan dalam penelitian pengembangan model pembelajaran motorik kasar untuk siswa TK kelompok A berupa pedoman wawancara dan angket observasi model, angket keefektifan model. Instrumen yang dipergunakan dibuat untuk menilai apakah produk yang telah dikembangkan baik dari aspek isi, tampilan dan aspek manfaat layak dipergunakan. Dalam pembuatan instrument peneliti meminta pendapat para ahli agar instrumen yang dibuat sesuai dengan karakteristik objek yang diteliti. Instrumen dalam penelitian ini menghasilkan dua jenis data yaitu data kualitatif dan kuantitatif. Berikut instrument yang dipergunakan:

\section{Pedoman Wawancara}

Pedoman wawancara yang dibuat pada penelitian ini dipergunakan sebagai panduan wawancara dengan guru TK sehingga pertanyan yang dilontarkan tidak menyimpang dari tujuan. Format wawancara pada penelitian ini adalah bebas terpimpin. Format bebas terpimpin dipilih karena dirasa paling tepat sehingga saat pewawancara melakukan pertanyaan, materi yang digali dapat dikembangkan sesuai arah jawaban dari narasumber dan penggalian informasi tidak kaku.

\section{Catatan Lapangan}

Catatan lapangan berfungsi untuk mendeskripsikan hasil pengamatan pada pelaksanaan pembelajaran. Deskripsi dilakukan dengan cara menulis hal-hal yang terjadi di lapangan yang terkait dengan permasalahan penelitian.

\section{Angket Skala Nilai}

Angket dipergunakan untuk menilai draf model permainan yang dikembangkan pada uji skala kecil, dan uji skala besar. penilaian angket dilakukan dengan menggunakan skala 4. Penilaian skala 4 atau dikenal dengan skala likert terdiri atas katagori: (1) tidak sesuai, (2) cukup sesuai, (3) sesuai, (4) sangat sesuai. 


\section{Jurnal Keolahragaan 4 (2), September 2016 - 191}

Nuridin Widya Pranoto

\section{Teknik Analisis Data}

Teknik analisis data yang digunakan dalam penelitian ini adalah analisis data deskriptif kuantitatif dan kualitatif. Teknik analisis data deskriptif kuantitatif dilakukan pada: (1) data skala nilai hasil penilaian para ahli materi terhadap draf awal model sebelum pelaksanaan uji coba di lapangan, (2) data hasil observasi oleh para ahli materi terhadap model, (3) data hasil observasi oleh para ahli materi terhadap keefektifan model, dan (4) data kuesioner siswa.

Rentang skor yang dipergunakan untuk menilai angket validasi, observasi model, dan observasi keefektifan model menggunakan tiga skala. Berikut skala yang dipergunakan: (1) skor 1 untuk penilaian tidak sesuai, (2) skor 2 untuk penilaian cukup sesuai, (3) skor 3 untuk penilaian sesuai. Hasil penilaian terhadap itemitem observasi dijumlahkan, lalu total nilai dikonversi untuk mengetahui kategori. Pengkonversian nilai dilakukan dengan mengacu pada standar Penilaian Acuan Patokan (PAP). Menurut Azwar (2005, p.109) dalam menginterpretasikan skor mentah menjadi nilai menggunakan pendekatan PAP. Berikut norma katagorisasi yang dipergunakan.

$\begin{array}{ll}X<(\mu-1,0 \sigma) & \text { rendah } \\ (\mu-1,0 \sigma) \leq X<(\mu+1,0 \sigma) & \text { sedang } \\ (\mu+1,0 \sigma) \leq X & \text { tinggi }\end{array}$

Dalam penelitian ini norma kategorisasi rendah diasumsikan sebagai tidak sesuai/tidak efektif, sedang sebagai cukup sesuai/cukup efektif, dan tinggi sebagai sesuai/efektif.

Teknik analisis deskriptif kualitatif dilakukan terhadap: (1) data hasil wawancara dengan guru TK pada studi pendahuluan, (2) data masukan dari para ahli materi terhadap model permainan baik sebelum uji coba maupun setelah uji coba di lapangan. Aktivitas analisis data model ini adalah reduksi data, penyajian data, dan membuat kesimpulan data.

\section{HASIL DAN PEMBAHASAN}

Proses revisi model pembelajaran motorik kasar siswa TK kelompok A mengalami 4 kali revisi, yaitu: (1) sebelum validasi, (2) sebelum uji coba produk dengan skala kecil, (3) setelah uji coba dengan skala kecil, dan (4) setelah uji coba dengan skala besar. Pada tahap uji draf, uji skala kecil, dan uji skala besar dilakukan penilaian (1) observasi terhadap kesesuaian model permainan, (2) efektivitas model oleh para ahli dan guru di lapangan. Hasil penilaian para ahli dan guru di lapangan adalah sebagai berikut:

\section{Penilaian Uji Draf}

Pada penilaian kesesuaian pelaksanaan uji draf yang terdiri atas 10 permainan motorik kasar siswa TK kelompok A ke tiga ahli memberi penilaian sebagai berikut: Permainan pertama tebak hewan berada pada interval $35 \leq$ $\mathrm{X}$ dengan katagori sesuai, permainan ke dua ular mencari makan berada pada interval $35 \leq \mathrm{X}$ dengan katagori sesuai, permainan ke tiga lari cheetah berada pada interval $35 \leq \mathrm{X}$ dengan katagori sesuai, permainan ke empat mencari hewan berada pada interval $35 \leq \mathrm{X}$ dengan katagori sesuai, permainan ke lima mengambil hewan berada pada interval $35 \leq \mathrm{X}$ dengan katagori sesuai, permainan ke enam loncat kangguru berada pada interval $35 \leq \mathrm{X}$ dengan katagori sesuai, permainan ketujuh lompat bangau berada pada interval $35 \leq \mathrm{X}$ dengan katagori sesuai, permainan ke delapan lubang tukus berada pada interval $35 \leq \mathrm{X}$ dengan katagori sesuai, permainan ke sembilan ikan sapu-sapu berada pada interval $35 \leq \mathrm{X}$ dengan katagori sesuai, permainan ke sepuluh gerka undur-undur berada pada interval $35 \leq \mathrm{X}$ dengan katagori sesuai. Berdasarkan penilaian tersebut diketahui bahwa ke sepuluh permainan pada uji draf dinyatakan sesuai dipergunakan pada pembelajaran motorik kasar siswa TK kelompok A.

Pada penilaian keefektifan pelaksanaan uji draf yang terdiri atas 10 permainan motorik kasar siswa TK kelompok A ketiga ahli memberi penilaian sebagai berikut: Permainan pertama tebak hewan berada pada interval $35 \leq$ $X$ dengan katagori efektif, permainan ke dua ular mencari makan berada pada interval $35 \leq \mathrm{X}$ dengan katagori efektif, permainan ke tiga lari cheetah berada pada interval $35 \leq \mathrm{X}$ dengan katagori efektif, permainan ke empat mencari hewan berada pada interval $35 \leq \mathrm{X}$ dengan katagori efektif, permainan ke lima mengambil hewan berada pada interval $35 \leq \mathrm{X}$ dengan katagori efektif, permainan ke enam loncat kangguru berada pada interval $35 \leq \mathrm{X}$ dengan katagori efektif, permainan ketujuh lompat bangau berada pada interval $35 \leq \mathrm{X}$ dengan katagori efektif, permainan ke delapan lubang tukus berada pada interval $35 \leq \mathrm{X}$ dengan katagori efektif, permainan ke sembilan ikan sapu-sapu berada pada interval $35 \leq \mathrm{X}$ dengan katagori efektif, permainan ke sepuluh gerka 
undur-undur berada pada interval $35 \leq \mathrm{X}$ dengan katagori efektif. Berdasarkan penilaian tersebut diketahui bahwa ke sepuluh permainan pada uji draf dinyatakan efektif dipergunakan pada pembelajaran motorik kasar siswa TK kelompok A.

\section{Penilaian Uji Skala Kecil}

Pada penilaian kesesuaian pelaksanaan uji skala kecil yang terdiri atas 10 permainan motorik kasar siswa TK kelompok A ke tiga ahli memberi penilaian sebagai berikut: Permainan pertama tebak hewan berada pada interval $35 \leq \mathrm{X}$ dengan katagori sesuai, permainan ke dua ular mencari makan berada pada interval $35 \leq \mathrm{X}$ dengan katagori sesuai, permainan ke tiga lari cheetah berada pada interval $35 \leq \mathrm{X}$ dengan katagori sesuai, permainan ke empat mencari hewan berada pada interval $35 \leq$ $X$ dengan katagori sesuai, permainan ke lima mengambil hewan berada pada interval $35 \leq \mathrm{X}$ dengan katagori sesuai, permainan ke enam loncat kangguru berada pada interval $35 \leq \mathrm{X}$ dengan katagori sesuai, permainan ketujuh lompat bangau berada pada interval $35 \leq \mathrm{X}$ dengan katagori sesuai, permainan ke delapan lubang tukus berada pada interval $35 \leq \mathrm{X}$ dengan katagori sesuai, permainan ke sembilan ikan sapu-sapu berada pada interval $35 \leq \mathrm{X}$ dengan katagori sesuai, permainan ke sepuluh gerka undur-undur berada pada interval $35 \leq \mathrm{X}$ dengan katagori sesuai. Berdasarkan penilaian tersebut diketahui bahwa ke sepuluh permainan pada uji skala kecil dinyatakan sesuai dipergunakan pada pembelajaran motorik kasar siswa TK kelompok A.

Pada penilaian keefektifan pelaksanaan uji skala kecil yang terdiri atas 10 permainan motorik kasar siswa TK kelompok A ketiga ahli memberi penilaian sebagai berikut: Permainan pertama tebak hewan berada pada interval $35 \leq$ $\mathrm{X}$ dengan katagori efektif, permainan ke dua ular mencari makan berada pada interval $35 \leq \mathrm{X}$ dengan katagori efektif, permainan ke tiga lari cheetah berada pada interval $35 \leq \mathrm{X}$ dengan katagori efektif, permainan ke empat mencari hewan berada pada interval $35 \leq \mathrm{X}$ dengan katagori efektif, permainan ke lima mengambil hewan berada pada interval $35 \leq \mathrm{X}$ dengan katagori efektif, permainan ke enam loncat kangguru berada pada interval $35 \leq \mathrm{X}$ dengan katagori efektif, permainan ketujuh lompat bangau berada pada interval $35 \leq \mathrm{X}$ dengan katagori efektif, permainan ke delapan lubang tukus berada pada interval $35 \leq \mathrm{X}$ dengan katagori efektif, permainan ke sembilan ikan sapu-sapu berada pada interval $35 \leq \mathrm{X}$ dengan katagori efektif, permainan ke sepuluh gerka undur-undur berada pada interval $35 \leq \mathrm{X}$ dengan katagori efektif. Berdasarkan penilaian tersebut diketahui bahwa ke sepuluh permainan pada uji skala kecil dinyatakan efektif dipergunakan pada pembelajaran motorik kasar siswa TK kelompok A.

Pengembangan model pembelajaran harus memperhatikan beberapa sudut pandang salah satunya tanggapan dari siswa. Tanggapan dari siswa penting diperhatikan karena siswa yang menjadi objek sasaran dari produk yang dibuat. Berikut tanggapan siswa akan model pembelajaran motorik kasar pada uji coba skala kecil. Pada pertanyaan pertama yang menanyakan apakah siswa senang melakukan aktivitas pembelajaran melalui model permainan motorik kasar bertemakan hewan menunjukkan bahwa $100 \%$ siswa menjawab senang atau memilih ikon senyum dan 0\% siswa menjawab tidak senang atau memilih ikon cemberut. Pada pertanyaan kedua yang menanyakan apakah siswa mudah melaksanakan aktivitas permainan motorik kasar bertemakan hewan menunjukkan bahwa 95\% siswa menjawab senang atau memilih ikon senyum dan 5\% siswa menjawab tidak senang atau memilih ikon cemberut. Pada pertanyaan ketiga yang menanyakan apakah siswa semangat melaksanakan aktivitas pembelajaran melalui model permainan motorik kasar bertemakan hewan menunjukkan bahwa 95\% siswa menjawab senang atau memilih ikon senyum dan 5\% siswa menjawab tidak senang atau memilih ikon cemberut. Pada pertanyaan keempat yang menanyakan apakah peralatan yang dipergunakan menarik, menunjukkan bahwa $90 \%$ siswa menjawab senang atau memilih ikon senyum dan $10 \%$ siswa menjawab tidak senang atau memilih ikon cemberut. Pada pertanyaan kelima yang menanyakan apakah peralatan yang dipergunakan aman, menunjukkan bahwa 95\% siswa menjawab senang atau memilih ikon senyum dan 5\% siswa menjawab tidak senang atau memilih ikon cemberut. Pada pertanyaan keenam yang menanyakan apakah peraturan permainan mudah di mengerti, menunjukkan bahwa $90 \%$ siswa menjawab senang atau memilih ikon senyum dan $10 \%$ siswa menjawab tidak senang atau memilih ikon cemberut. Pada pertanyaan ketuju yang menanyakan apakah permainan yang dilakukan aman, menunjukkan bahwa 95\% siswa menjawab senang atau memilih ikon senyum dan 5\% 


\section{Jurnal Keolahragaan 4 (2), September 2016 - 193}

Nuridin Widya Pranoto

siswa menjawab tidak senang atau memilih ikon cemberut.

\section{Penilaian Uji Skala Besar}

Pada penilaian kesesuaian pelaksanaan uji skala besar yang terdiri atas 10 permainan motorik kasar siswa TK kelompok A ke empat ahli memberi penilaian sebagai berikut: Permainan pertama tebak hewan berada pada interval $35 \leq \mathrm{X}$ dengan katagori sesuai, permainan ke dua ular mencari makan berada pada interval $35 \leq \mathrm{X}$ dengan katagori sesuai, permainan ke tiga lari cheetah berada pada interval $35 \leq \mathrm{X}$ dengan katagori sesuai, permainan ke empat mencari hewan berada pada interval $35 \leq$ $\mathrm{X}$ dengan katagori sesuai, permainan ke lima mengambil hewan berada pada interval $35 \leq \mathrm{X}$ dengan katagori sesuai, permainan ke enam loncat kangguru berada pada interval $35 \leq \mathrm{X}$ dengan katagori sesuai, permainan ketujuh lompat bangau berada pada interval $35 \leq \mathrm{X}$ dengan katagori sesuai, permainan ke delapan lubang tukus berada pada interval $35 \leq \mathrm{X}$ dengan katagori sesuai, permainan ke sembilan ikan sapu-sapu berada pada interval $35 \leq \mathrm{X}$ dengan katagori sesuai, permainan ke sepuluh gerka undur-undur berada pada interval $35 \leq \mathrm{X}$ dengan katagori sesuai. Berdasarkan penilaian tersebut diketahui bahwa ke sepuluh permainan pada uji skala besar dinyatakan sesuai dipergunakan pada pembelajaran motorik kasar siswa TK kelompok A.

Pada penilaian keefektifan pelaksanaan uji skala besar yang terdiri atas 10 permainan motorik kasar siswa TK kelompok A ketiga ahli memberi penilaian sebagai berikut: Permainan pertama tebak hewan berada pada interval $35 \leq$ $\mathrm{X}$ dengan katagori efektif, permainan ke dua ular mencari makan berada pada interval $35 \leq \mathrm{X}$ dengan katagori efektif, permainan ke tiga lari cheetah berada pada interval $35 \leq \mathrm{X}$ dengan katagori efektif, permainan ke empat mencari hewan berada pada interval $35 \leq \mathrm{X}$ dengan katagori efektif, permainan ke lima mengambil hewan berada pada interval $35 \leq \mathrm{X}$ dengan katagori efektif, permainan ke enam loncat kangguru berada pada interval $35 \leq \mathrm{X}$ dengan katagori efektif, permainan ketujuh lompat bangau berada pada interval $35 \leq \mathrm{X}$ dengan katagori efektif, permainan ke delapan lubang tukus berada pada interval $35 \leq \mathrm{X}$ dengan katagori efektif, permainan ke sembilan ikan sapu-sapu berada pada interval $35 \leq \mathrm{X}$ dengan katagori efektif, permainan ke sepuluh gerka undur-undur berada pada interval $35 \leq \mathrm{X}$ dengan katagori efektif. Berdasarkan penilaian tersebut diketahui bahwa ke sepuluh permainan pada uji skala besar dinyatakan efektif dipergunakan pada pembelajaran motorik kasar siswa TK kelompok A.

Pengembangan model pembelajaran harus memperhatikan beberapa sudut pandang salah satunya tanggapan dari siswa. Berikut tanggapan siswa akan model pembelajaran motorik kasar pada uji coba skala besar. Pada pertanyaan pertama yang menanyakan apakah siswa senang melakukan aktivitas pembelajaran melalui model permainan motorik kasar bertemakan hewan menunjukkan bahwa 100\% siswa menjawab senang atau memilih ikon senyum dan $0 \%$ siswa menjawab tidak senang atau memilih ikon cemberut. Pada pertanyaan kedua yang menanyakan apakah siswa mudah melaksanakan aktivitas permainan motorik kasar bertemakan hewan menunjukkan bahwa $100 \%$ siswa menjawab senang atau memilih ikon senyum dan $0 \%$ siswa menjawab tidak senang atau memilih ikon cemberut. Pada pertanyaan ketiga yang menanyakan apakah siswa semangat melaksanakan aktivitas pembelajaran melalui model permainan motorik kasar bertemakan hewan menunjukkan bahwa 94\% siswa menjawab senang atau memilih ikon senyum dan $6 \%$ siswa menjawab tidak senang atau memilih ikon cemberut. Pada pertanyaan keempat yang menanyakan apakah peralatan yang dipergunakan menarik, menunjukkan bahwa $91 \%$ siswa menjawab senang atau memilih ikon senyum dan 9\% siswa menjawab tidak senang atau memilih ikon cemberut. Pada pertanyaan kelima yang menanyakan apakah peralatan yang dipergunakan aman, menunjukkan bahwa 97\% siswa menjawab senang atau memilih ikon senyum dan 3\% siswa menjawab tidak senang atau memilih ikon cemberut. Pada pertanyaan keenam yang menanyakan apakah peraturan permainan mudah di mengerti, menunjukkan bahwa 100\% siswa menjawab senang atau memilih ikon senyum dan $0 \%$ siswa menjawab tidak senang atau memilih ikon cemberut. Pada pertanyaan ketujuh yang menanyakan apakah permainan yang dilakukan aman, menunjukkan bahwa $94 \%$ siswa menjawab senang atau memilih ikon senyum dan $6 \%$ siswa menjawab tidak senang atau memilih ikon cemberut.

Setelah dilakukan uji draf, uji skala kecil, dan uji skala besar dihasilkan produk pembelajaran motorik kasar siswa TK keompok A. 


\section{Jurnal Keolahragaan 4 (2), September 2016 - 194}

Nuridin Widya Pranoto

Berikut penjelasan pengembangan model pembelajaran motorik kasar siswa TK kelompok A:

Permainan Teak Hewan

Model permainan tebak hewan berkonsepkan membelajarkan gerak berjalan kepada siswa. Pada permainan ini siswa berjalan sesuai rute yang telah ditentukan sambil bernyanyi di antara kedua tangan teman yang diangkat ke atas dan saling berpegangan. Saat lagu selesai siswa yang berada di antara kedua tangan teman ditangkap. Siswa yang tertangkap memilih gambar pada kertas yang telah disediakan, setelah itu siswa memperagakan gerak hewan yang ada pada gambar. Permainan ini bertujuan mengembangkan kemampuan siswa untuk memiliki kesadaran tubuh, kesadaran ruang, kesadaran akan arah, konsentrasi dan membelajarkan berbagai jenis hewan kepada siswa

\section{Permainan Ular Mencari Makan}

Model permainan ular mencari makan berkonsepkan membelajarkan gerakan lari atau berjalan yang terkoordinasi antar siswa. Pada permainan ular siswa saling berpegangan pada pinggang teman satu kelompok dan berlari atau berjalan mengambil gambar hewan yang berada di lantai. Permainan ini bertujuan mengembangkan kemampuan gerak berjalan dan lari yang terkoordinasi serta mengembangkan kesadaran tubuh, kesadaran ruang, kesadaran akan arah, dan membelajarkan bentuk dan nama hewan.

\section{Permainan Lari Cheetah}

Permainan lari cheetah berkonsepkan membelajarkan gerakan lari yang terarah. Pada permainan ini siswa dituntut berlari secepatcepatnya menuju tempat yang ditentukan dan mengantisipasi apabila tujuan awal gagal diperoleh. Permainan ini bertujan membelajarkan siswa lari terarah, mengembangkan kemampuan siswa untuk memiliki kesadaran tubuh, kesadaran ruang, dan kesadaran akan arah, mengembangkan kemampuan gerak antisipasi siswa, melatih keseimbangan, dan konsentrasi siswa.

\section{Permainan Mencari Hewan}

Permainan mencari hewan berkonsepkan membelajarkan gerak lari kepada siswa. Pada permainan ini siswa diajarkan berlari dan mencari binatang yang diinstruksikan dan memperagakan gerak binatang menuju garis start kembali. Permainan ini bertujuan untuk membelajarkan gerak lari, mengembangkan kemam- puan siswa untuk memiliki kesadaran tubuh, kesadaran ruang, dan kesadaran akan arah, melatih keseimbangan siswa, meningkatkan konsentrasi siswa dan membelajarkan siswa berbagai bentuk hewan.

\section{Permainan Mengambil Hewan}

Permainan mengambil hewan berkonsepkan membelajarkan gerak meloncat. Pada permainan ini siswa berlari menuju gambar yang telah tersedia dan mengambil gambar yang digantung pada tali dengan cara meloncat. Permainan ini bertujuan membelajarkan gerak meloncat, melatih keseimbangan siswa, konsentrasi, dan membelajarkan siswa akan hewan berkaki empat dan dua.

\section{Permainan Loncat Kangguru}

Permainan loncat kangguru berkonsepkan membelajarkan gerak meloncat. Pada permainan ini siswa meloncat pada tempat yang telah disediakan dan pada akhir kotak siswa mengambil bola dan melemparkan pada kotak yang telah tersedia sebanyak tiga kali. Permainan ini bertujuan membelajarkan siswa meloncat dan melempar secara terarah, mengembangkan kemampuan siswa untuk memiliki kesadaran tubuh, kesadaran ruang, dan kesadaran akan arah, melatih keseimbangan, konsentrasi, dan mengenalkan siswa akan gerak kangguru.

\section{Permainan Lompat Bangau}

Permainan lompat bangau berkonsepkan membelajarkan gerak melompat kepada siswa. Pada permainan ini siswa melompat pada tempat yang disediakan dan pada kotak terakhir siswa menendang bola ke arah gawang sebanyak tiga kali. Permainan ini bertujuan membelajarkan gerak melompat dan menendang secara terarah, mengembangkan kemampuan siswa untuk memiliki kesadaran tubuh, kesadaran ruang, dan kesadaran akan arah, melatih keseimbangan dan konsentrasi.

\section{Permainan Lubang Tikus}

Permainan lubang tikus berkonsepkan membelajarkan siswa gerak merangkak. Pada permainan ini siswa merangkak masuk ke dalam lubang yang dibentuk dari kaki yang dilebarkan. Tujuan permainan ini membelajarkan siswa gerak merangkak, mengembangkan kekuatan tangan sebagai dasar gerak menggelantung, mengembangkan kemampuan siswa untuk memiliki kesadaran tubuh, kesadaran 


\section{Jurnal Keolahragaan 4 (2), September 2016 - 195 \\ Nuridin Widya Pranoto}

ruang, dan kesadaran akan arah, meningkatkan konsentrasi siswa.

Permainan Ikan Sapu-Sapu

Permainan menirukan gerak ikan sapusapu berkonsepkan membelajarkan siswa gerakan mendorong. Pada permainan ini siswa mendorong kain seperti gerakan membersihkan lantai. Permainan ini bertujuan meningkatkan kekuatan tangan sebagai dasar gerakan menggelantung, mengembangkan kemampuan siswa untuk memiliki kesadaran tubuh, kesadaran ruang, meningkatkan konsentrasi siswa.

Permainan Undur-Undur

Permainan gerak undur-undur berkonsepkan membelajarkan siswa mengangkat beban tubuh sendiri. Pada permainan ini siswa membentuk posisi tubuh seperti kayang kemudian bergerak pada rute yang telah ditentukan. Permainan ini bertujuan mengembangkan kekuatan tangan dan kaki sebagai dasar gerak menggelantung.

\section{SIMPULAN DAN SARAN}

\section{Simpulan}

Pada penelitian pengembangan model pembelajaran motorik kasar siswa TK kelompok A terdapat beberapa kesimpulan. Berikut kesimpulan pengembangan model pembelajaran motorik kasar siswa TK kelompok A:

Pertama, Pengembangan model pembelajaran motorik kasar melalui pendekatan bermain bertemakan hewan dengan metode research and development menghasilkan sepuluh permainan yaitu (1) permainan tebak hewan, (2) permainan ular mencari makan, (3) permainan lari citah, (4) permainan mencari hewan, (5) permainan mengambil hewan, (6) permainan loncat kangguru, (7) permainan lompat bangau, (8) permainan lubang tikus, (9) permainan ikan sapu-sapu, (10) permainan undur-undur. Kedua, Pengembangan model pembelajaran motorik kasar dengan pendekatan bermain menirukan gerak hewan efektif dipergunakan untuk pembelajaran motorik kasar siswa TK kelompok A. Ketiga, Pengembangan model pembelajaran motorik kasar dengan pendekatan bermain menirukan gerak hewan mendapatkan respon yang baik dari siswa TK kelompok A.

\section{Saran}

Saran pemanfaatan produk merupakan usulan yang dapat dipertimbangkan saat pemakaian produk. Berikut beberapa usulan pemanfaatan produk: Pertama, Produk ini disarankan dipergunakan pada pembelajaran motorik kasar siswa TK kelompok A. Kedua, Guru TK disarankan untuk melaksanakan model pembelajaran secara bertahap dari aktifitas yang mudah menuju aktifitas yang kompleks. Ketiga, Alat yang dipergunakan dalam proses pembelajaran dapat disesuaikan dengan kondisi sekolah.

\section{DAFTAR PUSTAKA}

Azwar, S. (2005). Penyusunan skala psikologi. Yogyakarta: Pustaka Pelajar.

Dharmamulya, S dkk. (2008). Permainan tradisional Jawa. Yogyakarta: Kepel Press.

Hughes, F.P. (2010). Children, play, and development, $\quad\left(4^{\text {th }} e d.\right)$. California: SAGE Publications, Inc.

Isjoni. (2009). Cooperative learning. Bandung: Alfabeta.

Partini. (2010). Pengantar pendidikan anak usia dini. Yogyakarta: Grafindo Litera Media.

Rusman. (2011). Model-model pembelajaran: mengembangkan profesionalisme guru. Jakarta: PT Raja Grafindo Persada.

Sukamti, E.R. (2007). Perkembangan motorik. Yogyakarta: Universitas Negeri Yogyakarta.

Sugiyanto. (2008). Model-model pembelajarn inovativ. Bandung: Alfabeta.

Sugiyono. (2011). Metode penelitian kuantitatif kualitatif dan $R \quad \& \quad D$. Bandung: Alfabeta. 